Jurnal Ilmu Ilmu Agribisnis: Journal of Agribusiness Science, 9(4), November 2021

\title{
NILAI TAMBAH DAN STRATEGI PENGEMBANGAN PRODUK PADA AGRONDUSTRI KOPI BUBUK CAP GUNUNG DI KABUPATEN WAY KANAN
}

\author{
(Added Value And Product Development Strategy Of Coffee Powder Agro-Industry Cap Gunung \\ In Way Kanan Regency)
}

Ragil Crysanti Wiryaningsih, Dwi Haryono, Lina Marlina

\begin{abstract}
Jurusan Agribisnis, Fakultas Pertanian, Universitas Lampung, Jl. Prof. Dr. Soemantri Brojonegoro No. 1, Bandar Lampung, 35145.e-mail: dwi.haryono@fp.unila.ac.id
\end{abstract}

\begin{abstract}
ABSRACT
This study aims to analyze and calculate the added value of Cap Gunung coffee powder agro-industry, and arrange the development strategy of Cap Gunung coffee powder agro-industry products. The method that used in this research is a case study. Therefore, the analytical method that used is the Hayami Method and Strength, Weakness, Opportunity, Threats (SWOT) Analysis. Based on the calculation of the value added is $R p 13,386 / \mathrm{kg}$ with a value added ratio is 32.81 percent. Furthermore, results of the SWOT analysis show that the values of internal and external factors are 78.8 and 64.9. This value indicate that the Cap Gunung coffee powder agro-industry in quadrant I, or in the Strength-Opportunity (SO) strategy. The priority strategy that can be implemented is to expand the marketing area, increase production output, and develop businesses by utilizing their strengths.
\end{abstract}

Keywords: added value, development strategy, hayami method, SWOT analysis

Received: 30 June 2020 Revised:14 August 2020 Accepted:17 Februaryt 2020 DOI: http://dx.doi.org/10.23960/jiia.v9i4.5400

\section{PENDAHULUAN}

Pertanian merupakan salah satu sektor penting di Indonesia yang terdiri dari subsektor perkebunan, tanaman pangan, perikanan, peternakan, dan kehutanan (Kementrian Pertanian 2011). Salah satu subsektor yang juga memberikan kontribusi bagi pendapatan negara adalah subsektor prekebunan. Menurut Direktorat Jendral Perkebunan (2019), Indonesia memiliki luas lahan perkebunan sebesar 27.358.747 ha, salah satunya perkebunan kopi yang hampir ada di setiap daerah di Indonesia dengan luas areal sebesar 1.258.032 dengan jumlah produksi 760.963 ton. Perkebunan kopi di Indonesia tersebar luas hampir di setiap pulau-pulau besar di Indonesia, sehingga terdapat berbagai jenis kopi yang terdapat di Indonesia.

Hampir seluruh kabupaten dan kota di Provinsi Lampung menghasilkan kopi dengan jenis robusta dengan luas lahan 156.821 ha, dengan jumlah produksi 110.264 ton (Direktorat Jendral Perkebunan 2019). Produksi kopi di Provinsi Lampung yang mengalami fluktuasi namun lebih sering mengalami peningkatan, mendorong banyaknya agroindustri yang tumbuh dan berkembang di Provinsi Lampung, terutama agroindustri yang bergerak di bidang pengolahan biji kopi.
Agroindustri memiliki peran penting bagi komoditas pertanian untuk diolah lebih lanjut. Agroindustri dapat mengubah bentuk maupun fungsi dari suatu komoditas pertanian yang diolah pada pasca panen. Agroindustri pengolahan biji kopi memiliki peran dalam meningkatkan nilai tambah suatu produk (Gaspersz 2001). Salah satu agroindustri kopi yang terdapat di Provinsi Lampung adalah agroindustri kopi bubuk Cap Gunung yang beralamat di Kampung Umpu Bhakti, Kabupaten Way Kanan. Agroindustri kopi bubuk Cap Gunung merupakan agroindustri yang mengolah biji kopi robusta menjadi kopi bubuk, sehingga dengan kegiatan pengolahan tersebut, agroindustri kopi bubuk Cap Gunung memperoleh nilai tambah dan menjadi keuntungan bagi pihak agroindustri.

Kabupaten Way Kanan menempati urutan keempat setelah Kabupaten Lampung Barat, Tanggamus, dan Lampung Utara dalam jumlah produksi kopi terbesar di Provinsi Lampung dengan jumlah produksi 8.722 ton (Direktorat Jendral Perkebunan 2019). Pemerintah Kabupaten Way Kanan memiliki program peningkatan produksi kopi dan pembinaan pelaku usaha penggilingan kopi. Pembinaan yang dilakukan untuk pelaku usaha penggilingan kopi adalah bantuan promosi dan pemasaran. Oleh karena itu, para pelaku usaha 
penggilingan kopi di Kabupaten Way Kanan sangat memanfaatkan program pemerintah. Di agroindustri kopi bubuk Cap Gunung, komposisi yang digunakan dalam proses produksi kopi sedikit berbeda dengan komposisi kopi bubuk pada umumnya. Agroindustri kopi bubuk Cap Gunung menggunakan biji kopi, jahe dan kakao dalam proses produksinya. Berdasarkan latar belakang yang telah dijabarkan, menjadi dasar perlu adanya penelitian strategi pengembangan produk sehingga pihak agroindustri kopi bubuk Cap Gunung dapat merumuskan strategi dalam mengembangkan bisnisnya. Tujuan penelitian ini adalah menganalisis nilai tambah agroindustri kopi Cap Gunung, dan menyusun strategi pengembangan produk agroindustri kopi bubuk Cap Gunung.

\section{METODE PENELITIAN}

Penelitian ini menggunakan metode studi kasus untuk mendalami secara rinci mengenai nilai tambah dan strategi pengembangan produk. Penelitian ini dilakukan di agroindustri kopi bubuk Cap Gunung di Kabupaten Way Kanan. Lokasi penelitian dipilih secara sengaja (purposive), dengan pertimbangan bahwa agroindustri kopi bubuk Cap Gunung sudah berdiri sejak 1990 di Kabupaten Way Kanan.

Metode analisis data yang digunakan dalam penelitian ini adalah analisis deskriptif kuantitatif dan analisis deskriptif kualitatif. Metode analisis deskriptif kuantitatif digunakan untuk menganalisa nilai tambah agroindustri kopi bubuk Cap Gunung dengan menggunakan metode Hayami. Metode analisis deskriptif kualitatif digunakan untuk menyusun strategi pengembangan produk agroindustri kopi bubuk Cap Gunung dengan menggunakan metode analisis SWOT (Strenght, Weakness, Opportunity, Threats).

Analisis SWOT merupakan alat analisis yang menggunakan informasi dari lingkungan perusahaan. Lingkungan perusahaan terdiri dari lingkungan internal dan lingkungan eksternal. Lingkungan internal perusahaan terdiri dari kekuatan dan kelemahan perusahaan, sedangkan lingkungan eksternal terdiri dari peluang dan ancaman yang dihadapi perusahaan. Dari proses pengumpulan data, diperoleh matriks faktor internal dan eksternal dengan bantuan kuisioner yang ditujukan kepada responden. Pengumpulan data penelitian ini dilakukan pada bulan Januari 2020.

\section{HASIL DAN PEMBAHASAN}

\section{Karakteristik Responden}

Jumlah responden dalam penelitian ini sebanyak 10 orang. Responden dalam analisis nilai tambah adalah pemilik agroindustri yang berusia 36 tahun, dengan latar belakang pendidikan Sekolah Menengah Atas (SMA). Responden analisis SWOT terdiri dari satu orang pemilik agroindustri, dua orang karyawan, dua orang pihak Dinas Perindustrian dan Perdagangan Kabupaten Way Kanan, dan lima orang konsumen kopi bubuk Cap Gunung.

Karakteristik responden diantaranya usia dan pendidikan. Usia konsumen berada pada rentang 24-36 tahun, dengan presentase usia 24-29 tahun sebesar 40 persen, dan presentase usia 30-36 tahun sebesar 60 persen. Usia karyawan berada pada pada rentang 22-23 tahun, dengan presentase usia 22 tahun sebesar 50 persen dan presentase usia 23 tahum sebesar 50 persen. Usia responden dari pihak Dinas Perindustrian dan Perdagangan Kabupaten Way Kanan berada pada rentang 25-43 tahun, dengan presentase usia 25 tahun sebesar 50 persen dan presentase usia 43 tahun sebesar 50 persen.

Karakteristik pendidikan konsumen berada pada rentang Sekolah Menengah Pertama (SMP) sampai dengan Diploma III (DIII), dengan presentase tingkat pendidikan SMP sebesar 20 persen, tingkat SMA dan DIII masing-masing sebesar 40 persen. Pendidikan karyawan 100 persen berada pada tingkat pendidikan SMA. Pendidikan responden dari pihak Dinas Perindustrian dan Perdagangan Kabupaten Way Kanan berada pada rentang SMA sampai Strata 2 (S2), dengan presentase tingkat pendidikan SMA 50 persen, dan S2 sebesar 50 persen.

\section{Proses Produksi Kopi Bubuk Cap Gunung}

Proses produksi kopi yang dilakukan oleh agroindustri kopi bubuk Cap Gunung, diantaranya adalah pengambilan bahan baku, pemilihan bahan baku, pencucian, penyangraian, pendinginan, penggilingan, pengemasan, dan pemasaran. Bahan baku pembuatan kopi bubuk terdiri dari biji kopi, dan terdapat bahan baku pendukung yaitu jahe, dan kakao. Bahan-bahan tersebut diperoleh dengan cara membeli. Biji kopi yang digunakan adalah biji kopi petik asalan, dengan kadar air 1220 persen. 
Proses pembuatan kopi bubuk dilakukan setiap hari dengan rata-rata produksi $150 \mathrm{~kg} / \mathrm{hari}$.

Proses pemilihan bahan baku dilakukan dengan cara memisahkan kopi biji yang masih tercampur dengan kulit ari. Biji kopi kemudian dicuci sebanyak dua kali dengan menggunakan air bersih, agar kulit ari yang masih terbawa pada proses pemisahan terbuang. Proses selanjutnya adalah penyangraian biji kopi selama empat jam menggunakan mesin penyangrai yang digerakkan dengan dynamo. Pada proses penyangraian dilakukan penambahan bahan pendukung, yaitu kakao dan jahe. Penambahan kakao dilakukan satu jam sebelum proses penyangraian berakhir, sedangkan penambahan jahe dilakukan setengah jam sebelum proses penyangraian berakhir.

Setelah disangrai, biji kopi didinginkan di atas tikar dan dikipas selama dua jam. Setelah biji kopi dingin, maka biji kopi digiling menggunakan mesin penggiling kopi (huller). Mesin huller digerakkan dengan tenaga solar. Proses penggilingan berlangsung selama satu jam. Kopi bubuk yang sudah digiling, kemudian dikemas dalam plastik berukuran 100 gram. Kemasan kopi 100 gram kemudian dikemas lagi menggunakan kardus yang dapat memuat lima kilogram kopi. Setelah dikemas ke dalam kardus, kopi bubuk siap untuk dipasarkan. Kopi bubuk dipasarkan dengan cara dikirim oleh pihak agroindustri kepada pedagang besar di Kabupaten Way Kanan.

Proses pemasaran dilakukan dengan sistem titip jual, dimana pihak agroindustri mengantarkan langsung produknya. Daerah pemasaran kopi bubuk Cap Gunung diantaranya Kecamatan Blambangan Umpu, Way Tuba, Banjit, Rebang Tangkas, dan Baradatu.

\section{Analisis Nilai Tambah}

Besarnya nilai tambah dapat diketahui dari hasil analisis nilai tambah yang diperoleh dari proses pengolahan biji kopi menjadi kopi bubuk. Nilai tambah agroindustri kopi bubuk Cap Gunung dapat dilihat pada Tabel 1 yang merupakan perhitungan nilai tambah dalam periode satu minggu.

Output yang dihasilkan dari proses produksi adalah $850 \mathrm{~kg} / \mathrm{minggu}$, dimana bahan baku yang digunakan yaitu $1.000 \mathrm{~kg}$ biji kopi, dengan bahan pendukung $5 \mathrm{~kg}$ kakao dan $5 \mathrm{~kg}$ jahe. Faktor konversi sebesar 0,85 , artinya tiap satu kilogram biji kopi menghasilkan 0,85 kilogram kopi bubuk.
Tabel 1. Perhitungan nilai tambah agroindustri kopi bubuk Cap Gunung per minggu

\begin{tabular}{|c|c|c|}
\hline \multicolumn{3}{|c|}{ Output (keluaran), input (masukan), dan harga } \\
\hline Output (kg/minggu) & A & 850 \\
\hline $\begin{array}{l}\text { Bahan baku } \\
(\mathrm{kg} / \text { minggu })\end{array}$ & B & 1.000 \\
\hline $\begin{array}{l}\text { Input tenaga kerja } \\
\text { langsung } \\
(\mathrm{HOK} / \mathrm{minggu})\end{array}$ & $\mathrm{C}$ & 19,25 \\
\hline $\begin{array}{l}\text { Faktor konversi (kg } \\
\text { output/kg bahan baku) }\end{array}$ & $\mathrm{D}=\mathrm{A} / \mathrm{B}$ & 0,85 \\
\hline $\begin{array}{l}\text { Koefisien tenaga kerja } \\
\text { (HOK/kg bahan baku) }\end{array}$ & $\mathrm{E}=\mathrm{C} / \mathrm{B}$ & 0,02 \\
\hline Harga output (Rp/kg) & $\mathrm{F}$ & 48.000 \\
\hline $\begin{array}{l}\text { Upah rata-rata tenaga } \\
\text { kerja }(\mathrm{Rp} / \mathrm{HOK})\end{array}$ & G & 27.381 \\
\hline \multicolumn{3}{|c|}{ Pendapatan dan keuntungan } \\
\hline $\begin{array}{l}\text { Harga input bahan } \\
\text { baku }(\mathrm{Rp} / \mathrm{kg})\end{array}$ & $\mathrm{H}$ & 23.000 \\
\hline $\begin{array}{l}\text { Sumbangan input lain } \\
(\mathrm{Rp} / \mathrm{kg})\end{array}$ & I & 4.414 \\
\hline Nilai output (Rp/kg) & $\mathrm{J}=\mathrm{D} * \mathrm{~F}$ & 40.800 \\
\hline $\begin{array}{l}\text { Nilai tambah }(\mathrm{Rp} / \mathrm{kg}) \\
\text { Rasio nilai tambah } \\
(\%)\end{array}$ & $\begin{array}{c}\mathrm{K}=\mathrm{J}-\mathrm{H}-\mathrm{I} \\
\mathrm{L} \%=\mathrm{K} / \mathrm{J} * 100\end{array}$ & $\begin{array}{c}13.386 \\
32,81\end{array}$ \\
\hline $\begin{array}{l}\text { Pendapatan tenaga } \\
\text { kerja }(\mathrm{Rp} / \mathrm{kg})\end{array}$ & $\mathrm{M}=\mathrm{E} * \mathrm{G}$ & 520,24 \\
\hline $\begin{array}{l}\text { Bagian tenaga } \\
\text { kerja }(\%)\end{array}$ & $\mathrm{N} \%=\mathrm{M} / \mathrm{K} * 100 \%$ & 3,89 \\
\hline $\begin{array}{l}\text { Keuntungan }(\mathrm{Rp} / \mathrm{kg}) \\
\text { Bagian keuntungan } \\
(\%)\end{array}$ & $\begin{array}{c}\mathrm{O}=\mathrm{K}-\mathrm{M} \\
\mathrm{P} \%=\mathrm{O} / \mathrm{J} * 100 \%\end{array}$ & $\begin{array}{c}12.866 \\
96,1\end{array}$ \\
\hline \multicolumn{3}{|c|}{ Balas jasa pemilik faktor-faktor produksi } \\
\hline Marjin $(\mathrm{Rp} / \mathrm{kg})$ & $\mathrm{Q}=\mathrm{J}-\mathrm{H}$ & 17.800 \\
\hline $\begin{array}{l}\text { Pendapatan tenaga } \\
\text { kerja }(\%)\end{array}$ & $\mathrm{R} \%=\mathrm{M} / \mathrm{Q} * 100 \%$ & 72,28 \\
\hline $\begin{array}{l}\text { Sumbangan input } \\
\text { lain }(\%)\end{array}$ & $\mathrm{S} \%=\mathrm{I} / \mathrm{Q} * 100 \%$ & 2,92 \\
\hline Keuntungan $(\%)$ & $\mathrm{T} \%=\mathrm{O} / \mathrm{Q} * 100 \%$ & 24,80 \\
\hline
\end{tabular}

Dari hasil perhitungan input tenaga kerja langsung, diperoleh nilai 19,25 HOK/minggu. Tenaga kerja pada agroindustri kopi bubuk Cap Gunung merupakan tenaga kerja langsung, yang meliputi proses produksi (pengambilan bahan baku, pemilihan bahan baku, pencucian, penyangraian, pendinginan, penggilingan) dan pengemasan. Rincan HOK dijelaskan pada Tabel 2.

Nilai sumbangan input lain diperoleh dari penjumlahan semua input yang digunakan, kecuali biaya bahan baku dan biaya tenaga kerja,

Tabel 2. Rincian HOK agroindustri kopi bubuk Cap Gunung

\begin{tabular}{lr}
\hline \multicolumn{1}{c}{ Pekerjaan } & HOK/minggu \\
\hline $\begin{array}{l}\text { Proses produksi (pengambilan } \\
\text { bahan baku, pemilihan bahan baku, }\end{array}$ & \\
$\begin{array}{l}\text { pencucian, penyangraian, } \\
\text { pendinginan, penggilingan) }\end{array}$ & 10,5 \\
Pengemasan & 8,75 \\
\hline Total & 19,25 \\
\hline
\end{tabular}


diantaranya adalah nilai kakao, jahe, plastik, kardus, biaya sablon, kayu bakar, solar, listrik, biaya transportasi pengambilan bahan baku, pajak, dan total penyusutan. Total penyusutan berasal dari alat-alat yang digunakan dalam proses produksi, yaitu tampi, ember, timbangan, mesin huller, kipas angin, dynamo, mesin penyaring, alat sablon, perekat, mobil, dan drum. Total nilai sumbangan input lain sebesar Rp 44.146 kg/bahan baku, atau Rp4.414/kg.

Nilai tambah yang dihasilkan dari pengolahan biji kopi menjadi kopi bubuk pada agroindustry kopi bubuk Cap Gunung adalah sebesar Rp13.386/kg, dengan rasio nilai tambah sebesar 32,81 persen. Penelitian ini didukung oleh Sari, Zakaria, dan Affandi (2015), bahwa nilai positif yang dihasilkan dari perhitungan nilai tambah, berarti bahwa suatu usaha layak dikembangkan untuk masa yang akan datang.

Besar marjin yang dihasilkan oleh agroindustri kopi bubuk Cap Gunung adalah Rp17.800/kg. Nilai marjin lebih besar dibandingkan dengan nilai tambah, karena nilai sumbangan input lain tidak dimasukkan dalam perhitungan marjin, Hasil penelitian Salsabila, Haryono, dan Syarif (2019), diperoleh nilai tambah sebesar Rp3.758,26 dengan marjin sebesar Rp8.089,12.

Perhitungan nilai tambah dapat mengetahui apakah suatu usaha bersifat padat modal atau padat karya, yang dapat diketahui dari besar proporsi tenaga kerja dan keuntungan terhadap nilai tambah. Agroindustri kopi bubuk Cap Gunung merupakan usaha yang bersifat padat karya, karena proporsi pendapatan tenaga kerja lebih besar dibandingkan dengan proporsi keuntungan. Proporsi pendapatan tenaga kerja sebesar 72,28 persen, sedangkan proporsi bagian keuntungan adalah 24,80 persen. Proporsi pendapatan tenaga kerja merupakan presentase terbesar dalam balas jasa faktor-faktor produksi pada agroindustri kopi bubuk Cap Gunung.

Dibandingkan dengan penelitian Sitorus, Lubis, dan Supriana (2015), nilai tambah proses produksi kopi bubuk robusta sebesar Rp206.400/3 kg, atau Rp68.800/kg, nilai tambah yang dihasilkan oleh agroindustri kopi bubuk Cap Gunung relatif rendah, yaitu sebesar Rp13.386. Hal ini dikarenakan nilai output yang dihasilkan agroindustri relatif kecil dan besar sumbangan input lain dan harga input relatif besar.

\section{Strategi Pengembangan Produk}

Analisis lingkungan agroindustri kopi bubuk Cap Gunung terdiri dari faktor internal dan eksternal. Penentuan faktor-faktor internal dan eksternal adalah dengan mewawancarai pemilik agroindustri dan Dinas Perdagangan dan Perindustrian Kabupaten Way Kanan. Setelah memperoleh faktor-faktor internal dan eksternal, kemudian mewawancarai responden untuk mengetahui rating dari masing- masing fakor. Rentang nilai pemberian rating adalah 1 sampai 4 .

Setelah diketahui nilai rating, kemudian menentukan nilai bobot dengan cara mengalikan rata-rata rating yang dimiliki masing-masing faktor dengan total bobot, dan dibagi dengan total rating. Total bobot menurut Rangkuti (2016) adalah 50 untuk faktor kekuatan, kelemahan, peluang, dan ancaman. Matriks faktor internal dapat dilihat pada Tabel 3. Matriks faktor eksternal dapat dilihat pada Tabel 4.

Tabel 3. Perhitungan matriks faktor internal

\begin{tabular}{|c|c|c|c|c|}
\hline No. & $\begin{array}{l}\text { Faktor strategi } \\
\text { internal }\end{array}$ & Rating & Bobot & $\begin{array}{c}\text { Skor } \\
\text { (rating } \\
\mathrm{x} \\
\text { bobot) }\end{array}$ \\
\hline \multicolumn{5}{|c|}{ Kekuatan (Stength): } \\
\hline 1. & $\begin{array}{l}\text { Harga jual yang tidak } \\
\text { terlalu mahal }\end{array}$ & 3,60 & 8,14 & 29,30 \\
\hline 2. & $\begin{array}{l}\text { Lokasi usaha yang } \\
\text { dekat dengan pasar }\end{array}$ & 3,60 & 8,14 & 29,30 \\
\hline 3. & $\begin{array}{l}\text { Adanya merk dagang } \\
\text { yang legal (terdaftar) }\end{array}$ & 3,70 & 8,37 & 30,97 \\
\hline 4. & $\begin{array}{l}\text { Teknologi yang } \\
\text { digunakan sudah } \\
\text { cukup modern } \\
\text { sehingga } \\
\text { menghasilkan produk } \\
\text { dalam jumlah besar }\end{array}$ & 3,80 & 8,60 & 32,68 \\
\hline 5. & $\begin{array}{l}\text { Produk memiliki ciri } \\
\text { khas }\end{array}$ & 3,80 & 8,60 & 32,68 \\
\hline 6. & $\begin{array}{l}\text { Pihak agroindustri } \\
\text { menerima kritik dan } \\
\text { saran }\end{array}$ & 3,60 & 8,14 & 29,30 \\
\hline Total & & 22,10 & 50 & 184,23 \\
\hline \multicolumn{5}{|c|}{ Kelemahan (Weakness): } \\
\hline 1. & $\begin{array}{l}\text { Kemasan masih } \\
\text { sederhana }\end{array}$ & 2,20 & 8,66 & 19,06 \\
\hline 2. & $\begin{array}{l}\text { Kurang melakukan } \\
\text { promosi }\end{array}$ & 3,20 & 12,60 & 40,31 \\
\hline 3. & $\begin{array}{l}\text { Jumlah karyawan } \\
\text { sedikit }\end{array}$ & 2,70 & 10,63 & 28,70 \\
\hline 4. & $\begin{array}{l}\text { Hanya ada } 1 \text { jenis } \\
\text { produk }\end{array}$ & 2,10 & 8,27 & 17,36 \\
\hline 5. & $\begin{array}{l}\text { Belum ada kerjasama } \\
\text { dengan pihak tertentu }\end{array}$ & 2,50 & 9,84 & 24,61 \\
\hline Total & & 12,70 & 50 & 105,43 \\
\hline
\end{tabular}




\section{a. Kekuatan:}

1) Harga jual kopi bubuk Cap Gunung tidak terlalu mahal

Agroindustri kopi bubuk Cap Gunung menjual produknya seharga Rp48.000/kg kepada pedagang besar atau pengecer. Oleh pedagang besar atau pengecer, dijual kepada konsumen seharga Rp50.000/kg. Jika dibandingkan dengan kopi merk lainnya dengan kualitas yang sejenis, harga kopi bubuk Cap Gunung relatif lebih murah.

2) Lokasi usaha yang dekat dengan pasar Lokasi pemasaran kopi bubuk Cap Gunung terbesar ada di Kecamatan Blambangan Umpu terutama di Pasar Pemda Way Kanan. Jarak dari agroindsutri ke Pasar Pemda Way Kanan adalah tiga kilometer, sehingga memudahkan dalam proses pengiriman produknya.

3) Adanya merk dagang yang legal (terdaftar) Kopi Cap Gunung memiliki merk dagang yang terdaftar di Badan Pengawas Obat dan Makanan tentang Pedoman Pemberian Sertifikat Produksi Pangan Industri Rumah Tangga nomor HK.031.23.04.12.2205 tanggal 30 April 2012.

4) Teknologi yang digunakan cukup modern Beberapa mesin yang dimiliki oleh agroindustri kopi bubuk Cap Gunung diantaranya adalah mesin pemisah biji dan kulit, mesin roaster, dan mesin huller.

5) Produk memiliki ciri khas

Kopi bubuk Cap Gunung menggunakan bahan baku utama biji kopi, dan yang menjadi ciri khas yaitu adamya campuran jahe dan kakao.

6) Menerima kritik dan saran

Pihak agroindustri kopi bubuk Cap Gunung memperhatikan keluhan konsumen terhadap produknya. Contohnya, ketika kemasan kopi mengalami kebocoran, maka pihak agroindustri kopi bubuk Cap Gunung memperbolehkan melakukan penukaran dengan produk yang baru.

\section{b. Kelemahan:}

1) Kemasan masih sederhana

Kopi dijual dalam kemasan 100 gram. Dalam kemasan tersebut tercantum logo kopi bubuk Cap Gunung, berat isi, komposisi, dan
Tabel 4. Perhitungan matriks faktor eksternal

\begin{tabular}{|c|c|c|c|c|}
\hline No. & $\begin{array}{l}\text { Faktor Strategi } \\
\text { Eksternal }\end{array}$ & Rating & Bobot & $\begin{array}{c}\text { Skor } \\
\text { (Rating x } \\
\text { Bobot) }\end{array}$ \\
\hline \multicolumn{5}{|c|}{ Peluang (opportunity): } \\
\hline 1. & $\begin{array}{l}\text { Dukungan dari } \\
\text { pemerintah } \\
\text { setempat }\end{array}$ & 3,70 & 17,45 & 64,56 \\
\hline 2. & $\begin{array}{l}\text { Peluang pasar } \\
\text { yang masih } \\
\text { terbuka }\end{array}$ & 3,60 & 16,98 & 61,13 \\
\hline 3. & $\begin{array}{l}\text { Pengembangan } \\
\text { usaha yang lebih } \\
\text { besar }\end{array}$ & 3,30 & 15,56 & 51,35 \\
\hline Total & & 10,60 & 50 & 185,09 \\
\hline \multicolumn{5}{|c|}{ Ancaman (thretas): } \\
\hline 1. & $\begin{array}{l}\text { Ketatnya } \\
\text { persaingan kopi } \\
\text { bubuk }\end{array}$ & 3,10 & 12,92 & 40,04 \\
\hline 2. & $\begin{array}{l}\text { Harga bahan baku } \\
\text { yang fluktuatif }\end{array}$ & 2,70 & 11,25 & 30,38 \\
\hline 3. & $\begin{array}{l}\text { Pembayaran hasil } \\
\text { penjualan oleh } \\
\text { pedagang besar } \\
\text { menemui } \\
\text { hambatan }\end{array}$ & 2,90 & 12,08 & 35,04 \\
\hline 4. & $\begin{array}{l}\text { Kenaikan harga } \\
\text { BBM dapat } \\
\text { mempengaruhi } \\
\text { aspek produksi } \\
\text { dan pemasaran }\end{array}$ & 1,30 & 5,42 & 7,04 \\
\hline 5. & $\begin{array}{l}\text { Munculnya } \\
\text { pesaing baru } \\
\text { dengan harga } \\
\text { yang lebih murah }\end{array}$ & 2,00 & 8,33 & 16,67 \\
\hline Total & & 12 & 50 & 130,04 \\
\hline
\end{tabular}

nomor izin edar produk Namun, belum memiliki informasi tanggal produksi, tanggal kadaluarsa, dan cara penyajian kopi.

2) Kurang melakukan promosi

Pemasaran produk yang dilakukan adalah dengan cara langsung kepada pedagang besar atau pengecer. Selain itu, promosi dilakukan dengan mengikuti pameran.

3) Jumlah karyawan sedikit

Karyawan yang dimiliki oleh agroindustri kopi bubuk Cap Gunung berjumlah sembilan orang. Terdiri dari tiga orang pekerja pria dan enam orang pekerja wanita. Masingmasing karyawan memiliki tugas yang berbeda, namun pada beberapa proses produksi, para pekerja harus saling membantu agar pekerjaan lebih cepat.

4) Hanya ada satu jenis produk

Produk yang dihasilkan oleh agroindustri kopi bubuk Cap Gunung adalah kopi bubuk, 
dan belum ada variasi produk lain.

5) Belum ada kerjasama dengan pihak tertentu Pihak agroindustri kopi bubuk Cap Gunung saat ini belum melakukan kerjasama dengan pihak manapun, misalnya dengan pihak penyedia modal atau reseller yang dapat memperkuat agroindustri.

\section{c. Peluang:}

1) Dukungan dari pemerintah setempat Dukungan yang diterima oleh agroindustri adalah penyuluhan tentang pengolahan dan pemasaran melalui pameran-pameran yang diselenggarakan di tingkat daerah.

2) Peluang pasar yang masih terbuka luas Meningkatnya peminat kopi saat ini, dapat menjadi peluang bagi agroindustri kopi bubuk Cap Gunung untuk memperluas pemasarannya. Terlebih, komposisi dalam kopi bubuk Cap Gunung sedikit berbeda dengan kopi pada umumnya.

3) Pengembangan usaha yang lebih besar Kapasitas produksi dan dukungan pemerintah menjadi peluang bagi pihak agroindustri kopi bubuk Cap Gunung dalam memperluas daerah pemasaran dan peningkatan kapasitas produksi.

\section{d. Ancaman:}

1) Ketatnya persaingan kopi bubuk Kebijakan pemerintah Kabupaten yang meningkatkan produksi kopi di Kabupaten Way Kanan menjadi ancaman bagi pelaku industri lama. Bukan tidak mungkin akan muncul pelaku-pelaku industri baru yang dapat menyaingi pelaku industri lama.

2) Harga bahan baku yang fluktuatif Apabila harga bahan baku fluktuatif, maka mempengaruhi keuntungan yang diperoleh oleh pihak agroindustri.

3) Pembayaran hasil penjualan menemui hambatan

Barang yang didistribusikan kepada pedagang besar, dibayarkan jika produk terjual. Menjadi ancaman bagi agroindustri jika hasil penjualan belum dibayarkan, karena hasil penjualan digunakan sebagai modal produksi selanjutnya.

4) Kenaikan harga BBM mempengaruhi aspek produksi dan pemasaran
Harga bahan bakar minyak mempengaruhi secara langsung biaya produksi kopi di agroindustri kopi bubuk Cap Gunung, karena agroindustry kopi bubuk Cap Gunung memiliki mesin produksi dan kendaraan yang menggunakan bahan bakar.

5) Munculnya pesaing baru dengan harga murah

Meningkatnya jumlah produksi kopi di Kabupaten Way Kanan mendorong munculnya pelaku usaha baru. Jika pelaku usaha baru mempunyai strategi yang lebih baik, promosi yang menarik dan modal yang besar, maka dapat menyaingi pelaku usaha lama seperti agroindustri kopi bubuk Cap Gunung.

\section{Pembobotan Matriks Untuk Diagram SWOT}

Setelah diketahui total nilai faktor internal dan eksternal, selanjutnya dapat melakukan pembobotan dengan menghitung selisih dari faktor internal dan eksternal. Dengan demikian, dapat digambarkan posisi keadaan suatu agroindustri. Posisi agroindustri kopi bubuk Cap Gunung dapat dilihat pada Gambar 1. Nilai selisih antara faktor internal dan faktor eksternal dapat dilihat pada Tabel 5.

Agroindustri kopi bubuk Cap Gunung berada pada kuadran I. Selaras dengan penelitian Putri, Sayekti, Rosanti (2014), bahwa suatu usaha layak dikembangkan karena agroindustri berada pada posisi kuadran I yang menguntungkan, karena berada dalam pertumbuhan (growth). Pertumbuhan yang dimaksud adalah pertumbuhan dalam hal penjualan, keuntungan, asset atau modal, atau kombinasi dari tiga hal tersebut. Agroindustri memiliki peluang yang dapat diraih dengan memanfaatkan kekuatan yang dimiliki.

Peluang (opportunity)

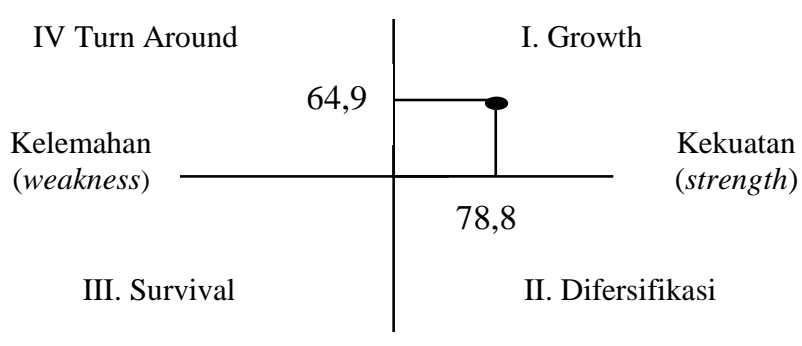

Ancaman (threats)

Gambar 1. Posisi keadaan agroindustri kopi bubuk Cap Gunung 
Tabel 5. Nilai selisih faktor internal dan faktor eksternal

\begin{tabular}{ccccc}
\hline \multirow{2}{*}{ Uraian } & \multicolumn{2}{c}{ Faktor internal } & \multicolumn{2}{c}{ Faktor eksternal } \\
\cline { 2 - 5 } & $\begin{array}{c}\text { Kekua- } \\
\text { tan }\end{array}$ & $\begin{array}{c}\text { Kelema- } \\
\text { han }\end{array}$ & Peluang & Ancaman \\
\hline Skor & 184,23 & 105,43 & 185,09 & 130,04 \\
\hline Selisih & \multicolumn{2}{c}{78,8} & \multicolumn{2}{c}{64,9} \\
\hline
\end{tabular}

Pertumbuhan yang dimaksud adalah pertumbuhan dalam hal penjualan, keuntungan, asset atau modal, atau kombinasi dari tiga hal tersebut. Agroindustri memiliki peluang yang dapat diraih dengan memanfaatkan kekuatan yang dimiliki.

Strategi yang dapat diterapkan untuk agroindustri kopi bubuk Cap Gunung adalah mendukung strategi pertumbuhan, dengan memperluas daerah pemasaran, meningkatkan hasil produksi, dan melakukan pengembangan usaha. Asmarantaka, Sayekti, dan Nugraha (2013), menyebutkan bahwa posisi perusahaan pada kuadran I memungkinkan suatu usaha untuk memperluas daerah pemasaran, karena didukung oleh kekuatan dan peluang yang dimiliki agroindustri.

\section{Strategi Prioritas}

Strategi prioritas dipilih berdasarkan relevansi terhadap visi, misi, dan tujuan agroindustri kopi bubuk Cap Gunung. Tujuan utama agroindustri kopi bubuk Cap Gunung adalah ikut andil dalam pengembangan industri pengolahan kopi di Provinsi Lampung. Adapun visi dan misi agroindustri kopi bubuk Cap Gunung periode 2014-2021 adalah sebagai berikut.

Visi:

Menjadi perusahaan industri pengolahan kopi yang terus berkembang dan mampu bersaing dalam era globalisasi dan menjadi industri kopi bubuk yang inovatif.

Misi:

1. Membantu pengembangan industri pengolahan kopi bubuk di Provinsi Lampung, sehingga Provinsi Lampung menjadi sentra industri kopi yang berpengaruh.

2. Mengelola perusahaan dengan sumberdaya manusia yang profesional.

3. Menggunakan teknologi modern yang ramah lingkungan.

4. Melakukan kemitraan yang berkesinambungan.
5. Membangun dan menciptakan lapangan pekerjaan dan memberdayakan penduduk setempat.

6. Memberikan manfaat sosial dan ekonomi untuk perusahaan, karyawan, serta lingkungan setempat.

Strategi prioritas yang dipilih dan sesuai dengan agroindustri kopi bubuk Cap Gunung sebagai berikut.

a. Strategi SO

1. Memperluas daerah pemasaran dengan memanfaatkan kekuatan produk yang dimiliki, seperti ciri khas dan legalitas, harga jual yang terjangkau, serta dukungan pemerintah.

2. Meningkatkan hasil produksi dengan memanfaatkan situasi, dimana saat kopi menjadi trend, dengan memanfaatkan teknologi yang dimiliki agroindustri.

3. Melakukan pengembangan dengan memanfaatkan legalitas produk, teknologi, keterbukaan terhadap kritik dan saran, dan ciri khas produk.

\section{b. Strategi WO}

1. Melakukan promosi dengan memanfaatkan dukungan pemerintah yang memberikan bantuan pemasaran.

2. Mengembangkan usaha dengan cara melakukan variasi produk dan bekerjasama dengan lembaga keuangan untuk meningkatkan kapasitas produksi dan diversifikasi produk.

c. Strategi ST

1. Memanfaatkan harga jual produk yang masih terjangkau dan legalitas produk untuk dapat bersaing dengan produk lainnya.

2. Mempertahankan kualitas produk, sehingga produk dapat bertahan apabila muncul pesaing baru.

\section{d. Strategi WT}

1. Melakukan kerjasama dengan reseller di berbagai wilayah di tengah ketatnya persaingan, sehingga produknya lebih dikenal secara luas.

\section{KESIMPULAN}

Agroindustri kopi bubuk Cap Gunung memberikan nilai tambah sebesar Rp13.386/kg dengan rasio nilai tambah 32,81 persen. Hasil analisis strategi pengembangan produk, menempatkan agroindustry kopi bubuk Cap Gunung berada pada kuadran I 
(growth). Strategi yang dapat diterapkan adalah: memperluas daerah pemasaran dengan memanfaatkan kekuatan produk yang dimiliki, meningkatkan hasil produksi kopi bubuk dengan memanfaatkan situasi trend kopi, dan mengembangkan usaha dengan memanfaatkan legalitas produk, keterbukaan terhadap kritik dan saran, atau kerjasama dengan pihak tertentu.

\section{DAFTAR PUSTAKA}

Asmarantaka A, Sayekti WD dan Nugraha A. 2013. Analisis strategi pengembangan usaha Bandrek Lampung pada unit usaha THP Herbalist. Jurnal Ilmu Ilmu Agribisnis, 1 (3): 195-199. http://jurnal.fp.unila.ac.id/index.php /JIA/article/view/573. [8 Juni 2020].

Direktorat Jendral Perkebunan. 2019. Produksi Perkebunan Kopi Di Indonesia Menurut Provinsi. Direktorat Jendral Perkebunan. Jakarta.

Gasperezs V. 2001. Ekonomi Manajerial Pembuatan Keputusan Agribisnis. Gramedia. Jakarta.

Kementrian Pertanian. 2011. Outlook Pertanian 2011-2025. Balitbang Kementrian Pertanian. Jakarta.

Putri D, Sayekti WD dan Rosanti N. 2014. Analisis pendapatan dan strategi pengembangan budidaya rumput laut di Pulau Pahawang Kecamatan Punduh Pidada
Kabupaten Pesawaran. Jurnal Ilmu Ilmu Agribisnis, 2 (1): 56-63.

http://jurnal.fp.unila.ac.id/index.php/JIA/article/vie w/561 [7 Mei 2020].

Rangkuti F. 2016. Teknik Membedah Kasus Bisnis Analisis SWOT. Gramedia Pustaka Utama. Jakarta.

Salsabila S, Haryono D dan Syarief YA. 2019. Analisis pendapatan dan nilai tambah agroindustri keripik pisang di Desa Sungai LangkaKecamatan Gedong Tataan Kabupaten Pesawaran. Jurnal Ilmu Ilmu Agribisnis, 7 (1): 68-74. http://jurnal.fp.unila. ac.id/index.php/JIA/article/view/3333/2554. [8 Juni 2020].

Sari IRM, Zakaria WA dan Affandi MI. 2015. Kinerja produksi dan nilai tambah agroindustri emping melinjo di Kota Bandar Lampung. Jurnal Ilmu Ilmu Agribisnis, 3 (1): $18-25$.

http://jurnal.fp.unila.ac.id/index.php/JIA/articl e/view/1013 [8 Juni 2020].

Sitorus UM, Lubis SN, Supriana T. 2015. Analisis nilai tambah dan pengembangan produk olahan kopi bubuk arabika (coffea arabica) di Desa Sait Buttu Saribu Kabupaten Simalungun. Jurnal Ekonomi Sosial dan $\begin{array}{llll}\text { Pertanian, } & 3 & \text { (9): } & 1-14\end{array}$ https://repository.unej.ac.id/handle/12345678 9/1963 [8 Oktober 2019]. 